\title{
In vitro Effect of $\alpha$-tocopherol and Ascorbic Acid Supplementation on Immunological Indicators in Bovine Leukocytes following Transportation
}

\author{
Renata Urban-Chmiel, Andrzej Wernicki, Andrzej Puchalski, Marta Dec \\ Institute of Biological Bases of Animal Diseases, Sub-Department of Veterinary Prevention, Faculty of \\ Veterinary Medicine, University of Life Sciences, Lublin, Poland \\ Received October 6, 2008 \\ Accepted May 18, 2009
}

\begin{abstract}
The aim of the present study was to evaluate the effect of two different antioxidants, $\alpha$-tocopherol and ascorbic acid, on the chemotactic activity and susceptibility to Mannheimia haemolytica leukotoxin (Lkt) of white blood cells obtained from calves exposed to transport in vitro.

Both antioxidants used were found to affect the chemotactic activity of white blood cells. Supplementation of $\alpha$-tocopherol at a concentration of $0.2 \mathrm{mg} / \mathrm{ml}$ and $0.5 \mathrm{mg} / \mathrm{ml}$ induced significant $(P \leq 0.05)$ increase of chemotactic activity in white blood cells compared to control. In case of ascorbic acid supplementation the highest chemotactic activity was observed at a concentration of $0.5 \mathrm{mg} / \mathrm{ml}$. The results obtained in microtitration (MTT) assay also suggest that high concentrations of $\alpha$-tocopherol $(0.5 \mathrm{mg} / \mathrm{ml})$ play a role in protecting bovine leukocytes against the cytotoxic effect of Lkt, the susceptibility of the leukocytes on $M$. haemolytica Lkt was lower in comparison to control about $6 \%$.

The antioxidants used in this study have been found to have a protective effect on cells participating in the immune response to $M$. haemolytica. This particularly applies to high concentrations of $\alpha$-tocopherol. The clinical aspect of these results may lie in protection of leukocytes exposed to leukotoxin of M. haemolytica.

It should be emphasized that the results provide only partial information on the effect of the antioxidants studied on cells participating in an organism's defence mechanisms. For an evaluation that would enable proper prevention of bovine respiratory diseases, research should be continued and expanded to include analysis of cellular structures.
\end{abstract}

Transport stress, Mannheimia haemolytica, leukotoxin, cell culture, chemotaxis, antioxidants

Bovine respiratory disease complex (BRDC) is the main cause of morbidity and mortality in feedlot cattle. Decreased serum antioxidant status and increased oxidative stress indicators after transport may play an important role in BRD development during the first four weeks after arrival to a new environment (Chirase et al. 2004). Previous studies (Urban-Chmiel 2006; Urban-Chmiel et al. 2006) have shown that transport stress has a major effect on the antioxidant and oxidative status in bovine leukocytes and increases their susceptibility to Mannheimia haemolytica leukotoxin (Lkt). These changes may play a negative role in $M$. haemolytica respiratory infection in calves.

Supplementation with certain antioxidants, such as $\beta$-carotene, $\alpha$-tocopherol or ascorbic acid improves the antioxidant status, cellular immune activity and cytokine production as well as inflammatory responses. Antioxidant administration may inhibit the inflammatory process by decreasing expression of cell adhesion molecules, reduce pro-inflammatory activity of neutrophils, i.e. inhibit pro-inflammatory cytokine production, but may enhance the anti-microbial activity of the leukocytes (Alvarado et al. 2006; EkstrandHammarström et al. 2006). In addition, increased supplementation of $\alpha$-tocopherol in vitro enhanced the chemotactic index but had no effect on antibody-dependent cellular cytotoxicity (Eicher et al. 1994). Administration of exogenous $\alpha$-tocopherol incorporated in liposomes protected against lung oedema in animal models of acute respiratory distress syndrome (ARDS) and against chemically induced lung injury by lipopolysaccharide (LPS) in a mouse model, which is correlated with antioxidant and oxidative status in cells.

Phone: +48814456036

Fax: +48 814456032

E-mail: renata.urban@up.lublin.pl

http://www.vfu.cz/acta-vet/actavet.htm 
High $\alpha$-tocopherol levels may be necessary to prevent peroxidative damage, and is also especially important in leukocytes, because immune function, and in particular phagocytic function, is linked to the release of $\mathrm{O}_{2}$ radicals that participate in the microbicidal activity of macrophages (Fan et al. 2000; Rocksén et al. 2003). Some authors (Baldi 2005; de la Fuente et al. 2000; Suntres and Shek 1997) suggest that both ascorbic acid and vitamin A have a similar effect to that of $\alpha$-tocopherol on the immunological properties of white blood cells (WBC), but this may depend on the concentration of these vitamins, which can influence an organism as pro- or antioxidants.

The stress reaction observed during transport can influence various metabolic processes. Most of these are connected with numerous biochemical changes related not only to proinflammatory factors but also to oxidative stress. The effect of these stressors is an increase in respiratory disease among transported calves during the first two weeks after transport (Winkler et al. 2007). Experiments on white blood cells exposed to transport stress may provide new knowledge about changes in immune functions in white blood cells that appear during transportation and may contribute to the development of bovine lung infection. Rivera et al. (2002) suggest that supplementation of diets with $\alpha$-tocopherol in calves produced a $12 \%$ to $27 \%$ decrease in the incidence of BRD.

The aim of the present study was to evaluate the influence of two different antioxidants, $\alpha$-tocopherol and ascorbic acid, on the immune functions and susceptibility to $M$. haemolytica leukotoxin of bovine leukocytes isolated from animals after transport.

\section{Materials and Methods}

Blood samples were collected into heparinised tubes from ten clinically healthy 8 -month-old calves immediately after a short-time (about 2-h) truck transport. The ambient temperature was about $18{ }^{\circ} \mathrm{C}$ and the calves were transported according to Council Regulation (EC) No 1/2005 of 22 December 2004.

Leukocytes for chemotaxis and MTT assay were isolated from the blood by the method described by Confer and Simsons (1986). After centrifugation at $1,800 \times g$ for $10 \mathrm{~min}$ at $4{ }^{\circ} \mathrm{C}$, cell suspension was washed with RPMI 1640 medium with 7\% BSA (Sigma, D), streptomycin $50 \mu \mathrm{g} / \mathrm{ml}$ and $1000 \mathrm{U} / \mathrm{ml}$ penicillin (Polfa Trachomin S.A.).

The cell cultures were incubated for $18 \mathrm{~h}$ at $37^{\circ} \mathrm{C}$ in RPMI 1640 medium supplemented with $7 \%$ BSA and the following concentrations of $\alpha$-tocopherol 500 IU (Sigma, D) or ascorbic acid (Sigma, D): $0.1 \mathrm{mg} / \mathrm{ml}, 0.2 \mathrm{mg}$ / $\mathrm{ml}$ and $0.5 \mathrm{mg} / \mathrm{ml}$, as described by van Dam et al. (2003) and according to the results obtained in our earlier experiments (Urban-Chmiel et al. 2009). After incubation, the cell cultures were centrifuged at $1,850 \times g, 4{ }^{\circ} \mathrm{C}$ for $10 \mathrm{~min}$, cells were harvested in RPMI 1640 medium for analysis.

Chemotactic activity (migration assay) was determined using a microchemotaxis technique and a 48-well modified Boyden chamber (Neuro Probe, USA) as described by Caswell et al. (1999). Homologous zymosan-activated serum was used as the chemotactic factor. As control, only RPMI 1640 medium with 7\% BSA was used. Cell migration proceeded in an incubator with humidified air with $5 \% \mathrm{CO}_{2}$ for 45 min. Leukocyte migration was expressed as chemotactic index in percent values (according to a procedure described by Alves et al. 1996), defined as the number of cells that migrated towards a sample divided by the number of leukocytes that migrated towards a medium control.

The obtained results were calculated as follows:

$\mathrm{cf}=($ chemotactic factor-induced cell migration / spontaneous cell migration $)-1 \times 100 \%$

Susceptibility of leukocytes to the cytotoxic effect of Lkt M. haemolytica was determined using a microtitration assay (MTT) as described by Vega et al. (1987). The results were calculated in percentage as follows:

$\%$ cytotoxicity $=[(\mathrm{OD}$ of toxin-treated cells/OD of toxin-untreated cells $)] \times 100($ Vega et al. 1987).

For comparison of cell losses during incubation, cells incubated in RPMI 1640 medium without antioxidant supplements were also used in the MTT assay.

The viability of isolated cells was evaluated using the trypan blue reduction test (Kandefer-Szerszen et al. 1993). For estimation of viability cells also MTT assay was used (Vega et al. 1987).

The results were analyzed using Statistica 6.0. Student's $t$-test $(P \leq 0.05)$ was used for comparisons between control and antioxidant-supplemented cells. The results obtained in cell viability between the concentrations of antioxidants were analysed statistically using ANOVA.

\section{Results}

Cultures of leukocytes isolated from calves subjected to transport stress grown in RPMI 1640 medium supplemented with $\alpha$-tocopherol or ascorbic acid showed increased chemotactic activity towards the chemotactic factor. The chemotactic index values for the cultures grown in media containing $0.1 \mathrm{mg} / \mathrm{ml} \alpha$-tocopherol or ascorbic acid were 


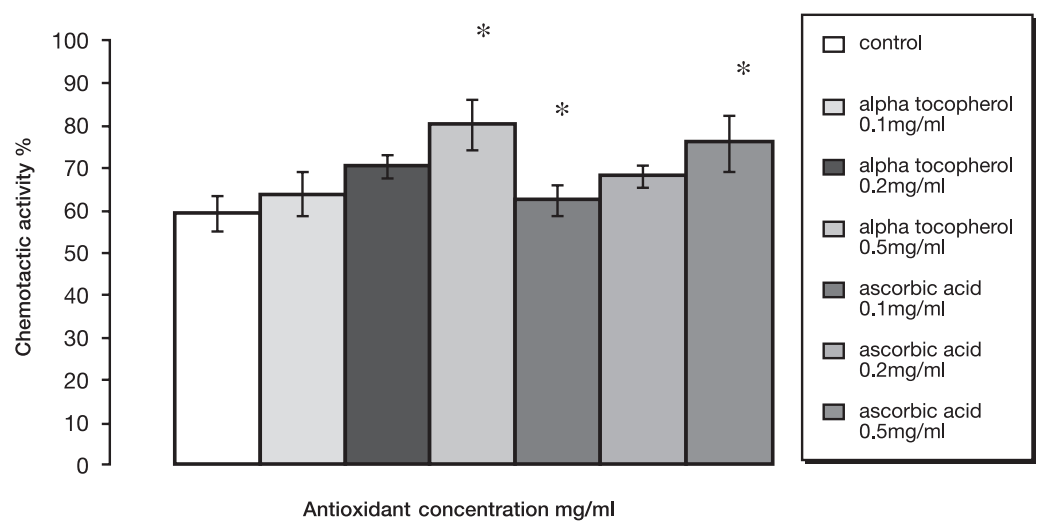

Fig. 1. Chemotactic activity of the leukocytes from cell culture in RPMI 1640 medium with $\alpha$-tocopherol or ascorbic acid supplementation $(\mathrm{x} \pm \mathrm{SEM})$

slightly higher than for the cells incubated without antioxidants (Fig. 1), and differences were not significant $(P \geq 0.05)$. The cell cultures grown in media containing $0.2 \mathrm{mg} / \mathrm{ml}$ and $0.5 \mathrm{mg} / \mathrm{ml}$ of $\alpha$-tocopherol showed significantly increased $(P \leq 0.05)$ chemotaxis towards the chemotactic factor under in vitro conditions. Expressed as percentages, the values obtained were about $20 \%$ higher than those obtained in the case of cells grown in RPMI 1640 medium without antioxidant supplements. Incubation of the cells in a medium supplemented with ascorbic acid at a concentration of $0.5 \mathrm{mg} / \mathrm{ml}$ also caused a substantial increase in chemotactic activity compared to control (Fig. 1).

Incubation of leukocytes isolated from calves after transport in a medium containing $\alpha$-tocopherol significantly reduced the sensitivity of the cells to the cytotoxic effects of Lkt $M$. haemolytica. It should be emphasised that a significant $(P \leq 0.05)$ effect was found in leukocytes from the culture containing $\alpha$-tocopherol at a concentration of $0.5 \mathrm{mg} / \mathrm{ml}$. In the case of cells incubated in an RPMI 1640 medium supplemented with ascorbic acid, no significant effect in cell sensitivity to leukotoxin was observed (Fig. 2). There were no significant differences in the results obtained.

Incubation of leukocytes with $\alpha$-tocopherol or ascorbic acid supplementation showed a very high viability of approximately $89 \%$. The cells incubated with $0.5 \mathrm{mg} / \mathrm{ml}$ of $\alpha$-tocopherol or

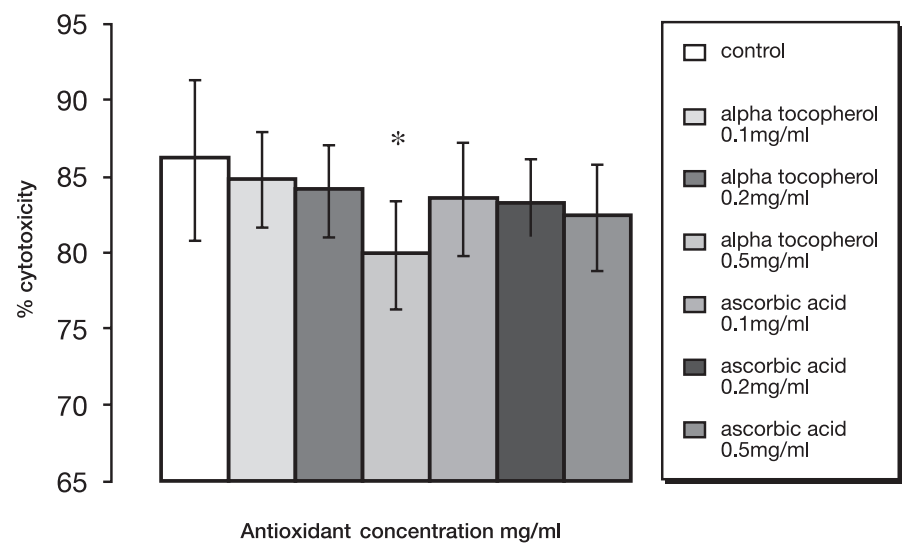

Fig. 2. Susceptibility of the leukocytes from cell culture in RPMI 1640 medium with $\alpha$-tocopherol or ascorbic acid supplementation on Lkt $M$. haemolytica cytotoxic effect $(\mathrm{x} \pm \mathrm{SEM})$ 
ascorbic acid showed a significantly higher $(P \leq 0.05)$ viability compared to control. There were no significant differences in mean cell viability between the cell cultures incubated

Table 1. The mean viability of leukocytes from cell culture in RPMI 1640 medium with $\alpha$-tocopherol or ascorbic acid supplementation $(\mathrm{x} \pm \mathrm{SD})$

\begin{tabular}{|l|l|c|c|}
\hline $\begin{array}{l}\text { Antioxidant } \\
\text { concentration } \mathrm{mg} / \mathrm{ml}\end{array}$ & $\alpha$-tocopherol & Ascorbic acid & Control \\
\hline 0.1 & $87.4 \pm 0.5$ & $87.0 \pm 0.3$ & $85.8 \pm 0.7$ \\
\hline 0.2 & $88.0 \pm 0.2$ & $87.5 \pm 0.6$ & - \\
\hline 0.5 & $88.9 \pm 0.5^{*, \mathrm{a}}$ & $88.3 \pm 0.2^{*, \mathrm{a}}$ & - \\
\hline
\end{tabular}

* Significant differences $(P \leq 0.05)$ in comparison to control

a) Differences between concentrations of antioxidants in the two examined antioxidants (Table 1).

\section{Discussion}

This study has shown that $\alpha$-tocopherol and ascorbic acid cause a significant increase in the chemotactic activity of leukocytes isolated from cattle after transport. It was also found that these antioxidants had a slight influence on stabilisation of viability of the cells. And in the main part of the experiment, the antioxidants used had a substantial effect on susceptibility of the cells on $M$. haemolytica leukotoxin. Particularly the high concentrations of $\alpha$-tocopherol decreased cell sensitivity to the cytotoxic effects of Lkt $M$. haemolytica.

The chemotactic activity assay confirmed the results obtained by Politis et al. (1996), who found that giving $\alpha$-tocopherol supplements to preparturient dairy cows caused a twofold increase in the chemotactic index of leukocytes. Additionally, in studies conducted by Eicher etal.(1994), incubation of bovine leukocytes in a medium supplemented with vitamin A and $\alpha$-tocopherol significantly increased their chemotactic index, with the highest values observed in the case of incubation in a medium with $1 \mathrm{mg} / \mathrm{ml} \alpha$-tocopherol. Other research found that chemotactic activity of cells from cultures grown in a medium with vitamin A or both $\alpha$-tocopherol and vitamin A was substantially lower than that of neutrophils obtained from cultures grown in a medium supplemented with only $\alpha$-tocopherol. On the other hand, no significant influence of these antioxidants on phagocytic activity was observed compared to cells incubated in a supplement-free medium (Bergman et al. 2004).

In our research, significant chemotactic activity was observed in $0.2 \mathrm{mg} / \mathrm{ml}$ of $\alpha$-tocopherol supplementation in growth medium. In the present study, chemotactic activity of the cells from cultures grown in an RPMI 1640 medium with a supplement of $\alpha$-tocopherol at a concentration of $0.5 \mathrm{mg} / \mathrm{ml}$ was higher than the activity of cultures grown in an RPMI 1640 medium supplemented with ascorbic acid. Based on the results obtained, it can be assumed that $\alpha$-tocopherol has a decidedly greater effect on activity of leukocytes.

This also applies to the proliferation response of lymphocytes, which may also be associated with decreased production of prostaglandin $\mathrm{E}_{2}$, correlated with increased production of IL-2, as shown in research by Beharka et al. (1997). Other studies (de la Fuente et al. 2000; Politis et al. 1996) have shown that $\alpha$-tocopherol given as a supplement to the diet of guinea pigs has a significant effect on the chemotactic activity of lymphocytes and macrophages. It should be emphasised here that the chemotactic index was dependent on the antioxidant content in the feed, rising as the concentration increased. In the present study, $\alpha$-tocopherol at a concentration of $0.1 \mathrm{mg} / \mathrm{ml}$ did not cause an increase in the chemotactic activity of leukocytes, as it did at concentrations of $0.2 \mathrm{mg} / \mathrm{ml}$ and $0.5 \mathrm{mg} / \mathrm{ml}$. Contrasting results were obtained in research on mice by Alvarado et al. (2006) who observed a significant increase in the chemotactic activity of macrophages after administration of small amounts of $\alpha$-tocopherol or ascorbic acid. There have also been changes observed in human subjects given both antioxidants, including changes in the production of inflammatory cytokines IL-1F2 and TNF- $\alpha$, which was found to be significantly greater than in the case of cells isolated from subjects who received only $\alpha$-tocopherol or ascorbic acid.

However, it is very difficult to adjust the optimal concentration of the antioxidant for 
immunological and physiological conditions because in many cases, low doses are not effective and high doses of several antioxidants can result in deleterious effects (Alvarado et al. 2006; Jeng et al. 1996). In the study of Alvarado et al. (2006), different doses of antioxidants used as a supplement of diet in mice enhanced the macrophage phagocytosis index and efficiency and lymphocyte chemotaxis index.

Based on the results of the present study, it can be concluded that $\alpha$-tocopherol is an effective antioxidant that limits destructive changes in cells caused by various external factors. Evaluation of leukocyte sensitivity to the cytotoxic effects of Lkt $M$. haemolytica also showed that more effective protection was achieved using higher concentrations of $\alpha$-tocopherol than ascorbic acid; $\alpha$-tocopherol significantly decreased the cytotoxic effects of the exotoxin on the cells studied. Probably, high concentrations $(0.5 \mathrm{mg} / \mathrm{ml})$ of $\alpha$-tocopherol and ascorbic acid may increase the stabilisation of cell-membrane structures. We also observed in the present study a significant influence of the antioxidants used on the viability of cells, which suggests an increase of their resistance to environmental factors. Some authors suggest that supplementing the diet of feeder calves with the antioxidant $\alpha$-tocopherol produces a $12-27 \%$ reduction in the incidence of BRDC and improved performance and recovery rate, particularly from IBR infection (Chirase et al. 1994).

In conclusion, the antioxidants used in this study have been found to have a protective effect on cells participating in the immune response to $M$. haemolytica. This particularly applies to high concentrations of $\alpha$-tocopherol. The clinical aspect of these results may be helpful in protection of leukocytes exposed to leukotoxin of M. haemolytica.

It should be emphasized that the results provide only partial information on the effect of the antioxidants studied on cells participating in an organism's defence mechanisms. For a comprehensive evaluation that would enable proper prevention of bovine respiratory syndrome, research should be continued and expanded to include analysis of cellular structures, such as those associated for example with TLR-4 receptors.

\section{Vliv in vitro suplementace $\alpha$-tokoferolu a kyseliny askorbové na vybrané imunologické ukazatele bovinních leukocytů po transportu}

Cílem této studie bylo zhodnotit vliv dvou různých antioxidantů, $\alpha$-tokoferolu a kyseliny askorbové, na chemotaktickou aktivitu a vnímavost bílých krvinek in vitro vliv vůči působení leukotoxinu Mannheimia haemolytica (Lkt). Bílé krvinky byly získány od telat vystavených účinkům transportu.

Oba antioxidanty ovlivnily chemotaktickou aktivitu bílých krvinek. Př́idavek $\alpha$-tokoferolu v koncentraci $0.2 \mathrm{mg} / \mathrm{ml} \mathrm{a} 0.5 \mathrm{mg} / \mathrm{ml}$ vyvolala signifikantní $(P \leq 0.05)$ vzestup chemotaktické aktivity leukocytů ve srovnání s kontrolou. Výsledky získané v mikrotitračním testu (MTT) naznačují, že vysoké koncentrace $\alpha$-tokoferolu $(0.5 \mathrm{mg} / \mathrm{ml})$ hrají roli v ochraně bovinních leukocytů proti cytotoxickému účinku Lkt. Vnímavost leukocytů vůči M. haemolytica Lkt byla asi o $6 \%$ nižší než u kontrol.

Antioxidanty použité v naší studii měly protektivní účinek na buňky, účastnící se imunitní odpovědi na $M$. haemolytica. Týká se to zejména vysoké koncentrace $\alpha$-tokoferolu. Klinické využití těchto výsledků může spočívat v ochraně leukocyti̊ vystavených leukotoxinu M. haemolytica.

Je však nutné zdůraznit, že naše výsledky podávají pouze předběžnou informaci o vlivech sledovaných antioxidantů na buňky, které jsou součástí obranných mechanismů organismu. Výsledky dalšího rozšířrení a prohloubení tohoto výzkumu na analýzu celulárních struktur umožní náležitou prevenci bovinních respiračních nemocí.

\section{Acknowledgements}

This work was supported by the Ministry of Scientific Research and Information Technology, Grant No. 2 P06K 03729. 


\section{References}

Alvarado C, Álvares P, Puerto M, Gausseres N, Jimenez L, De la Fuente M 2006: Dietary supplementation with antioxidants improves functions and decreases oxidative stress of leukocytes from prematurely aging mice. Nutrition 22: 767-777

Alves AC, Pires ALA, Cruz HN, Serra MF, Diaz BL, Cordeiro RSB, Lagente V, Martins MA, Silva PMR 1996 : Selective inhibition of phosphodiesterase type IV supresses the chemotactic responsiveness of rat eosinophils in vitro. Europ J Pharmacol 312: 89-96

Baldi A, 2005: Vitamin E in dairy cows. Livest Prod Sci 98: 117-122

Beharka AA, Wu DY, Han SN, Meydani SN 1997: Macrophage prostaglandin production contributes to the ageassociated decrease in $\mathrm{T}$ cell function which is reversed by the dietary antioxidant vitamin $\mathrm{E}$ mechanism. Ageing Develop 93: 56-77

Bergman M, Galman H, Djaldetti M, Fish L, Punsky I, Bessler H 2004: In vitro immune response of human periphrenal blood cells to vitamins C and E. J Nutr Biochem 15: 45-50

Caswell JL, Middleton DM, Gordon JR, 1999: Production and functional characterization of recombinant bovine interleukin-8 as a specific neutrophil activator and chemoattractant. Vet Immunol Immunopathol 67: 327-340

Chirase NK, Greene LW, Purdy CW, Loan RW, Auvermann BW, Parker DB, Walborg EF, Stevenson DE, Xu Y, Klaunig JE 2004: Effect of transport stress on respiratory disease, serum antioxidant status, and serum concentrations of lipid peroxidation biomarkers in beef cattle. Am J Vet Res 65: 860-864

Chirase NK, Hutcheson DP, Thompson GB, Spears JW, 1994: Recovery rate and plasma zinc and copper concentrations of steer calves fed organic and inorganic zinc and manganese sources with or without injectable copper and challenged with infectious bovine rhinotracheitis virus. J Anim Sci 72: 212-218

Confer AW, Simons KR 1986 : Effects of Pasteurella haemolytica lipopolysaccharide on selected functions of bovine leukocytes. Am J Vet Res 47: 154-157

Van Dam B, Van Hinsbergh VWM, Stehouwer CDA, Versteilen A, Dekker H, Buytenhek R, Princen HM, Schalwijk CG 2003 : Vitamin E inhibits lipid peroxidation-induced adhesion molecule expression in endothelial cells and decreases soluble cell adhesion molecules in healthy subjects. Cardiovascular Res 57: 563-571

Eicher SD, Morril L, Blecha F 1994: Vitamin concentration and function of leukocytes from dairy calves supplemented with vitamin A, E, $\beta$-carotene in vitro. J Dairy Sci 77: 560-565

Ekstrand-Hammarström B, Österlund C, Lilliehöök B, Bucht A 2006: Vitamin E down-modulates mitogenactivated protein kinases, nuclear factor- $\mathrm{B}$ and inflammatory responses in lung epithelial cells. Clin Exp Immunol 147: 359-369

Fan JF, Shek PN, Suntres ZE, Li YH, Orepoulos GD, Rotstein OD 2000: Liposomal antioxidants provide prolongated protection against acute respiratory distress syndrome. Surgery 28: 332-338

De la Fuente M, Carazo M, Correa R, Delrio M 2000: Changes in macrophage and lymphocyte functions in guinea-pigs after different amounts of vitamin E ingestion. Br J Nutr 84: 25-29

Jeng, KC, Yang CS, Siu WY, Tsai YS, Liao WJ, Kuo JS 1996: Supplementation with vitamins C and E enhances cytokine production by peripheral blood mononuclear cells in healthy adults. Am J Clin Nutr 64: 960-965

Kandefer-Szerszeń M 1993. Immunology exercises. UMCS, Faculty of Biology and Earth Sciences, Lublin

Politis I, Hidiroglou N, White JH, Gilmore JA, Williams SN, Scherf H, Frigg M 1996: Effect of vitamin E on mammary and blood leukocyte function, with emphasis on chemotaxis, in periparturient dairy cows. Am J Vet Res 57: 468-471

Rivera JD, Duff GC, Galyean ML, Walker DA, Nunnery GA 2002: Effect of supplemental Vitamin E on performance, health and humoral immune response of beef cattle. J Anim Sci 80: 933-941

Rocksén D, Ekstrand-Hammarström B, Johansson L, Bucht A 2003: Vitamin E reduces transendothelial migration of neutrophils and prevents lung injury in endotoxin-induced airway inflammation. Am J Resp Cell Mol Biol 28: 199-207

Suntres Z, Shek PN 1997: Protective effect of liposomal $\alpha$-tocopherol against bleomycin-induced lung injury. Biomed Environ Sci 10: 47-59

Urban- Chmiel R 2006: The influence of transport stress on oxidative stress parameters in bovine leukocytes. Slov Vet Res 43 (suppl. 10): 241-244

Urban- Chmiel R, Puchalski A, Wernicki A 2006: The influence of transport stress on susceptibility of the leukocytes on $M$. haemolytica leukotoxin. Medycyna Wet 62: 1045-1047

Urban-Chmiel R, Kankofer M, Wernicki A, Albera E, Puchalski A 2009: The influence of different doses of $\alpha$-tocopherol and ascorbic acid on selected oxidative stress parameters in in vitro culture of leukocytes isolated from transported calves. Livestock Sci 124: 89-92

Vega MV, Maheswaran SK, Leininger JR, Ames TR 1987: Adaptation of a colorimetric microtitration assay for quantifying Pasteurella haemolytica A1 leukotoxin and antileukotoxin. Am J Vet Res 48: 1559 - 1564

Winkler C, Schroecksnadel K, Schennach H, Fuchs D 2007: Vitamin C and E suppress mitogen-stimulated periphrenal blood mononuclear cells in vitro. Int Archiv Allerg Immunol 142: 127-132 